\title{
Spatial and temporal distribution patterns of ichthyoplankton in a region affected by water regulation by dams
}

\author{
Tatiane M. Gogola ${ }^{1}$, Vanessa S. Daga ${ }^{1}$, Pedro R. L. da Silva ${ }^{1}$, Paulo V. Sanches ${ }^{2,3}$, \\ Éder A. Gubiani ${ }^{3}$, Gilmar Baumgartner ${ }^{3}$ and Rosilene L. Delariva ${ }^{4}$
}

The aim of this work was to study the occurrence of ichthyoplankton in a region affected by water regulation by dams. The study area was located in the region of Ilha Grande National Park, upper Paraná River floodplain. Specifically, we examined the temporal and spatial distribution of Ichthyoplankton, identified spawning areas and established the relationships between the abundances of fish eggs and larvae and some limnological and hydrological variables. Samples were taken monthly between October and March from 2001 to 2005 at 24 sampling sites. For analytical purposes, the sampling sites were grouped into upper, middle and lower areas. The upper area of the National Park had the highest egg density and should be considered the primary spawning area. The middle area should be considered a drift area, and the lower area likely functions as a growth and feeding habitat. Statistical analyses showed that the spawning was influenced by water temperature, $\mathrm{pH}$, fluviometric level and rainfall, and that larval density was influenced by $\mathrm{pH}$, conductivity, dissolved oxygen and rainfall. The results also revealed that the tributaries apparently are used as migratory routes by fish, and and this shows the need to protect these sites.

O objetivo deste trabalho foi estudar a ocorrência de ictioplâncton em uma região sob influência de barragens. A área de estudo está localizada na região do Parque Nacional de Ilha Grande, planície de inundação do Alto Rio Paraná. Especificamente, analisamos a distribuição temporal e espacial do ictioplâncton, identificando áreas de desova e estabelecendo relações entre a abundância de ovos e larvas de peixes e algumas variáveis limnológicas e hidrológicas. Amostras foram coletadas mensalmente entre outubro e março de 2001 a 2005 em 24 pontos de amostragem. Para fins de análise as estações de amostragens foram agrupadas em área superior, média e inferior. A parte superior da área do Parque Nacional apresentou a maior densidade de ovos e pode ser considerada como local de desova, enquanto que a área central pode ser considerada local de deriva, e a área inferior funciona como um provável local de crescimento e alimentação das larvas. As análises estatísticas mostraram que as desovas foram influenciadas pela temperatura da água, $\mathrm{pH}$, nível fluviométrico e precipitação, e que a densidade de larvas foi influenciada pelo $\mathrm{pH}$, condutividade, oxigênio dissolvido e precipitação. Os resultados também revelaram que os afluentes aparentemente são utilizados como rotas migratórias de peixes, e isso demonstra a necessidade de proteção destes locais.

Key words: Ichthyoplankton, Ilha Grande National Park, Fish distribution, Fish spawning.

\footnotetext{
'Pós-Graduação em Recursos Pesqueiros e Engenharia de Pesca, Universidade Estadual do Oeste do Paraná. Rua da Faculdade, 645, 85903000 Toledo, PR, Brazil. tatigogola@yahoo.com.br (TMG), vanedaga@yahoo.com.br (VSD), pedropesca@yahoo.com.br (PRLS)

${ }^{2}$ Pós-Graduação em Biotecnologia Aplicada à Agricultura, Departamento de Biologia, Universidade Paranaense. Praça Mascarenhas de Moraes, s/n, Umuarama, PR, Brazil. pvsanches@yahoo.com.br

${ }^{3}$ Centro de Engenharia e Ciências Exatas, Grupo de Estudos em Recursos Pesqueiros e Limnologia (GERPEL), Pós-Graduação em Recursos Pesqueiros e Engenharia de Pesca, Universidade Estadual do Oeste do Paraná. Rua da Faculdade, 645, 85903-000 Toledo, PR, Brazil. egubiani@yahoo.com.br(ÉAG),gilmar_baum@yahoo.com.br(GB)

${ }^{4}$ Centro Universitário de Maringá. Av. Guedner, 1610, 87050-900 Maringá, PR, Brazil. rldelariva@uol.com.br
} 


\section{Introduction}

Ichthyoplankton studies have attempted to identify the occurrence of certain species in certain areas during certain time periods, and also to understand how this distribution affects the recruitment process (Miller, 2002). According to Baumgartner et al. (2004), the identification of spawning areas and natural fish nurseries is of fundamental importance for designing and implementing measures to protect these areas, with the goal of maximizing recruitment and maintaining fish stocks.

Determinations of the temporal and spatial distribution of eggs and fish larvae have provided relevant information about the annual variation in reproduction that result from both natural processes and management measures (Nakatani et al., 2001). Moreover, a better understanding of the abiotic variables that influence fish behavior and improved knowledge about the relationships between the abundance and distribution of fish eggs and larvae and environmental conditions in spawning and nursery areas is critical for management (Matsuura, 1977).

There are annual variations in the reproductive patterns of species, especially variations related to the area and the time of spawning. Generally, these depend on the environmental conditions required by the species or population for successful reproduction according to their life history. The dynamics between reproductive processes and environmental conditions directly affect the distribution of the species as well as spawning (Vazzoler, 1996).

In a river, the construction of dams and formation of reservoirs is one of the most obvious forms of impacts (Agostinho et al., 1992); where they are built, dams alter water flow and terrestrial and aquatic systems in a drastic and permanent way (Tundisi, 1999; Nilsson \& Berggren, 2000). In river-floodplain systems, impoundments usually modify the original river water regime. This directly affects connectivity and, consequently, biodiversity, especially that of isolated habitats (Petry et al., 2003; Gubiani et al., 2007). Currently, the Paraná River has about 130 dams higher than $10 \mathrm{~m}$, many of them in cascades. Of these dams, 26 have areas greater than $100 \mathrm{~km}^{2}$ (Agostinho et al., 1995). Prior to 1998, the hydrological regime of the Paraná River was strongly seasonal with pronounced wet and dry periods (Agostinho et al., 2004). The control of the hydrological regime by dam operations upstream is a serious threat to the maintenance and integrity of river-floodplain systems. Ilha Grande National Park, located between the Itaipu Reservoir and Porto Primavera Dam (Sérgio Motta Hydroelectric Power Plant), represents the last dam-free stretch of the Brazilian part of the Paraná River. While under the influence of the two reservoirs, this region still has no dammed tributaries, and these tributaries provide alternative migration routes for rheophilic fish to use as spawning areas.

In this region, little is known about the occurrences of eggs and larvae, the reproductive dynamics or the spawning areas of the fish species present in Ilha Grande National Park. The only studies of ichthyoplankton ecology in this region are those of Baumgartner et al. (2004, 2008), who identified the fish spawning areas above Ilha Grande National Park in the upper Paraná River floodplain. Thus, the present study sought to assess fish spawning areas by analysis of spatial and temporal distribution patterns of ichthyoplankton of a region under the effects of water regulation by dams in the Ilha Grande National Park, upper Paraná River floodplain. Specifically, this study intends to investigate: i) The existence of spawning areas, drift and development and, ii) The relationships between some environmental factors and the patterns of occurrence and distribution of ichthyoplankton in the Ilha Grande National Park.

\section{Material and Methods}

\section{Study area}

The study area was located in the Paraná River, which forms a natural boundary between Paraná and Mato Grosso do Sul States. It is representative of the Ilha Grande archipelago, which is composed of a complex of approximately 157 islands of varied sizes. The Ilha Grande National Park is located in the Southern region of the floodplain of the upper Paraná River between $23^{\circ} 16^{\prime}$ and $24^{\circ} 14^{\prime} \mathrm{S}$ and $53^{\circ} 43^{\prime}$ and $54^{\circ} 14^{\prime} \mathrm{W}$, and it has a total area of 75,894 ha and a perimeter of 242,163 km (Campos, 2001).

Ilha Grande is the largest island of the archipelago, approximately $80 \mathrm{~km}$ long and $5 \mathrm{~km}$ wide, and it divides the Paraná River into two channels. The presence of many islands makes the river an anastomosed channel with different flow characteristics, shallow secondary channels $(\sim 2 \mathrm{~m})$ and deep main channels $(>12 \mathrm{~m})$. Floodplains are present on both sides of the river, and they are under the influence of the hydrological dynamics of the Paraná River and its direct tributaries.

Several tributaries are present along this stretch, such as the Piquiri River, which is located on the left margin in Paraná State, and the Amambaí and Iguatemi Rivers, which are tributaries of the right margin in the Mato Grosso do Sul State. These tributaries all provide alternative routes for large migratory species to use for reproduction. These rivers are dam-free, and their flow characteristics are dependent only upon the hydrological cycle. Apart from these tributaries, this region has several marginal lagoons, which have intermittent or permanent connections with the Paraná River or with the secondary channels.

\section{Sampling}

For this work, we established 24 sampling sites, distributed across the main channel of the Paraná River and its main tributaries and marginal lagoons, to cover the entire area surrounding Ilha Grande National Park. For analytical purposes, the sampling sites were grouped into upper $(1,2,3$, $4,12,13$ and 14), middle $(5,6,15,16,17,18,23$ and 24$)$ and lower $(7,8,10,9,11,19,20,21$ and 22) areas (Fig. 1). 
Sampling was carried out monthly (at night) from October 2001 to March 2002 (period I), October 2003 to March 2004 (period II) and October 2004 to March 2005 (period III), using a plankton net $(0.5 \mathrm{~mm}$ mesh size) with a flow meter to measure the filtered water volume. At the lotic sampling sites, the net was submerged $10 \mathrm{~cm}$ against the current for $10 \mathrm{~min}$, and at the lentic sites, the net was towed with the boat at low speed. Samples were preserved in $4 \%$ formalin buffered with calcium carbonate $\left(\mathrm{CaCO}_{3}\right)$. The abundances of fish eggs and larvae were standardized to a volume of $10 \mathrm{~m}^{3}$ of filtered water according to Tanaka (1973), modified by Nakatani et al. (2001).

Concomitantly with the fish egg and larval collections, water samples were taken to measure some abiotic variables: $\mathrm{pH}$, water temperature $\left({ }^{\circ} \mathrm{C}\right)$, conductivity $\left(\mu \mathrm{S} \times \mathrm{cm}^{-1}\right)$ and dissolved oxygen $\left(\mathrm{mg} \times \mathrm{l}^{-1}\right)$. In addition to these, the variation in fluviometric level and rainfall were also determined. These data were obtained from SUDERHSA (Superintendência de Desenvolvimento de Recursos Hídricos e Saneamento Ambiental), from the hydrometeorological station in the municipality of Guaíra (Paraná State).

\section{Analysis}

The identification of the fish eggs and larval species captured was performed according to Nakatani et al. (2001). The average abundances for each site were obtained by dividing the total number of fish eggs or larvae captured by the number of samplings in each site.

To determine whether there were significant differences between the averages of egg and larval abundances between areas, periods and months available, one-way ANOVAs were applied (the main effects ANOVA was not significant). We tested the assumptions of normality and homoscedasticity using the Shapiro-Wilk and Levene tests, respectively. When the one-way ANOVA was significant and assumptions were met, the Tukey test was applied to determine significant differences. If the assumptions of ANOVA were not met, we used the rank transform method (Quinn \& Keough, 2002). We transformed data to ranks, and then the parametric ANOVA model was applied to ranked data (Conover \& Iman, 1981), checking the homoscedasticity in the ranked data. If the assumptions of ANOVA were still not met, we used the similar non-parametric test (Kruskal-Wallis; Zar, 1999).

To determine the influence of environmental variables on the temporal and spatial distribution of fish eggs and larval assemblages, summarized by abundances, correlation analyses (Spearman) were applied. Analyses of variance and correlations were performed using the software Statistica ${ }^{\mathrm{TM}}$ 7.0. The statistical significance level adopted was $p<0.05$.

\section{Results}

A total of 8,029 eggs were collected during sampling, with the greatest abundance collected in period I (2001-2002, 6.32 eggs $\left./ 10 \mathrm{~m}^{3}\right)$, followed by period II (2002-2004, 4.14 eggs/10 $\mathrm{m}^{3}$ ) and then period III (2004-2005, 2.76 eggs/10 $\left.\mathrm{m}^{3}\right)$ (Fig. 2a).
The highest monthly abundances of eggs were recorded in October $\left(9.31 \mathrm{eggs} / 10 \mathrm{~m}^{3}\right)$ and November $\left(7.79 \mathrm{eggs} / 10 \mathrm{~m}^{3}\right)$ (Fig. 2b). The upper area of the Ilha Grande National Park presented the highest average catch $\left(8.56 \mathrm{eggs} / 10 \mathrm{~m}^{3}\right)$, while the middle and lower areas had similar abundance values $(2.38$ and $2.29 \mathrm{eggs} / 10 \mathrm{~m}^{3}$, respectively) (Fig. 2c).

The abundance data were rank-transformed to meet the assumptions of ANOVA. One-way ANOVAs confirmed the existence of spatial and temporal differences in egg abundances. For the periods $(\mathrm{F}=11.508 ; \mathrm{p}<0.01)$, the Tukey test showed that period III was different from periods I and II. For the months $(\mathrm{F}=11.165 ; \mathrm{p}<0.01)$, the Tukey test showed that October and November were different from the others. For the areas $(\mathrm{F}=14.081 ; \mathrm{p}<0.01)$, the Tukey test showed that upper area was different from the middle and lower areas.

A total of 25,190 larvae were collected during sampling, with the highest catch recorded during period I (20.19 larvae $/ 10 \mathrm{~m}^{3}$ ) followed by period III (10.15 larvae/10 $\mathrm{m}^{3}$ ) (Fig. 3a). For the average monthly abundances, January was the highest (43.62 larvae $\left./ 10 \mathrm{~m}^{3}\right)$, followed by December and February $(9.54$ and 5.54 larvae $/ 10 \mathrm{~m}^{3}$, respectively) (Fig. 3b). For sites, the larvae tendency was the opposite that observed for the eggs, and the lower area had the highest abundance of larvae $\left(20.77\right.$ larvae $\left./ 10 \mathrm{~m}^{3}\right)$. Larval abundance was lower in the middle area $\left(9.13\right.$ ind. $\left./ 10 \mathrm{~m}^{3}\right)$ and the

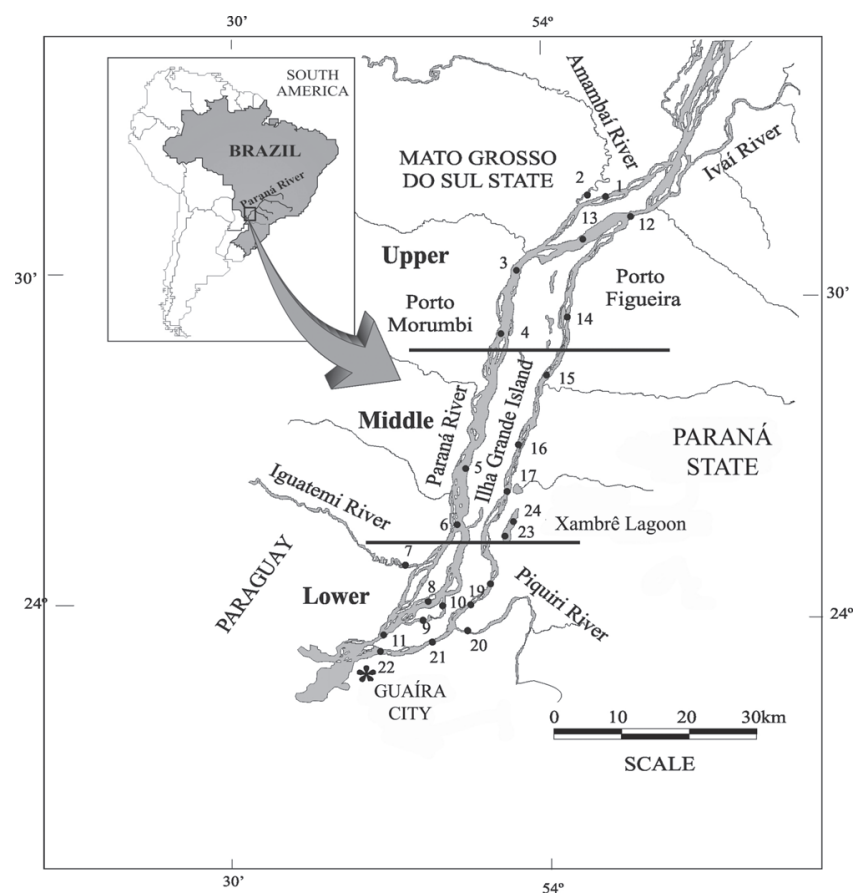

Fig. 1. Location of the sampling sites in the Ilha Grande National Park (1: Bandeirantes right channel; 2: Amambaí; 3: Triângulo; 4: Porto Santo Antônio; 5: Peruzzi; 6: Paraná/ Iguatemi; 7: Iguatemi; 8: Paraná/Saraiva; 9: Saraiva middle; 10: Saraiva Channel; 11: Ilha Grande right channel; 12: Bandeirantes left channel; 13: Ilha Grande Pontal; 14: Alvarenga; 15: Esmeralda; 16: Três Coqueiros; 17: São João; 18: Porto Luiz; 19 Porto Cerâmica; 20: Piquiri; 21: Porto Terra Roxa; 22 Ilha Grande left channel; 23: Xambrê River; 24: Xambrê middle). 

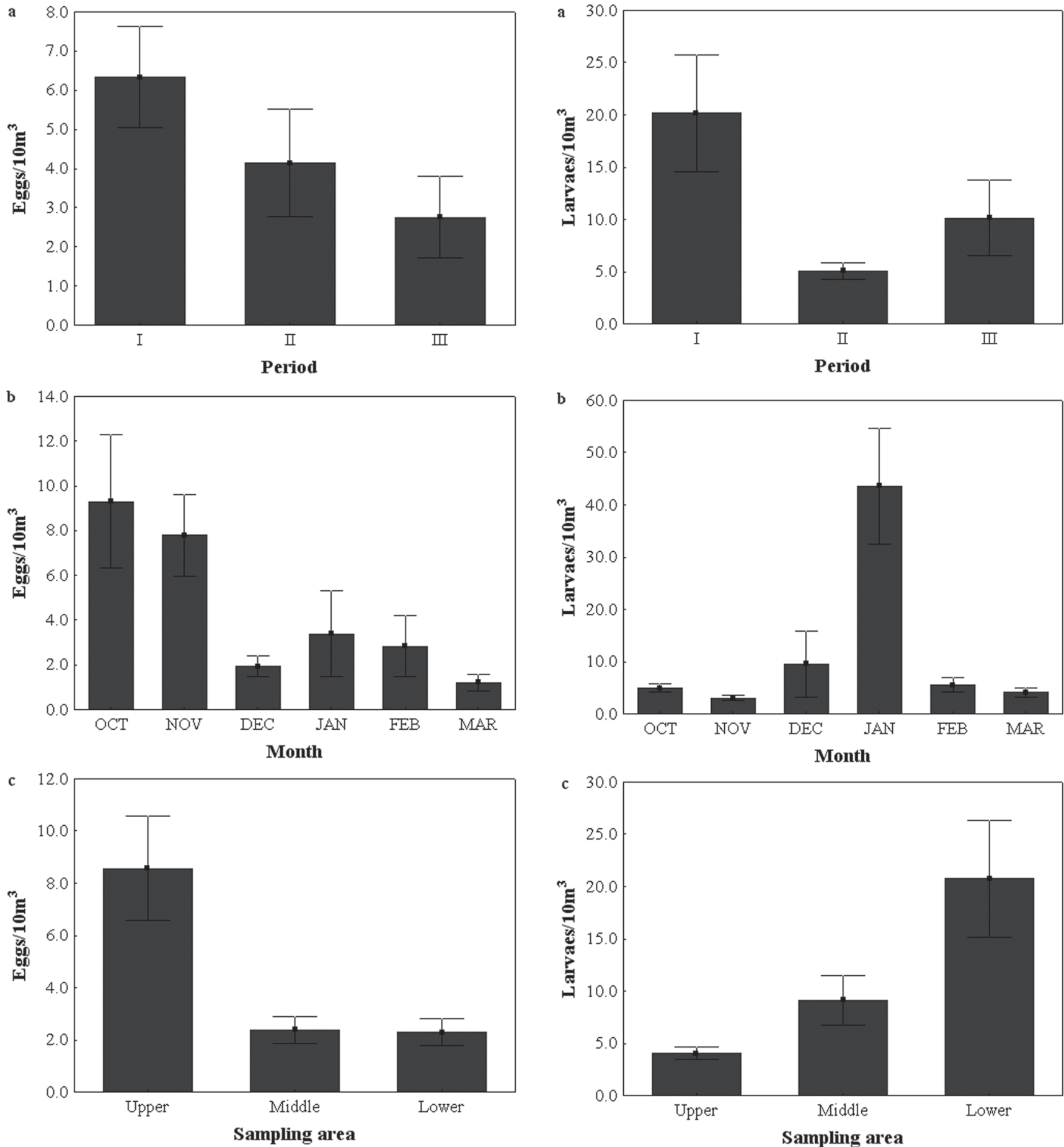

Fig. 2. Average egg abundances (rectangles) and standard errors (bars) by period (a), month (b) and sampling area (c) in the Ilha Grande National Park, from October 2001 to March 2005.

lowest in the upper area $\left(4.05\right.$ ind. $\left./ 10 \mathrm{~m}^{3}\right)$ (Fig. 3c).

Significant differences in larval abundances were verified for months and areas. For the months $(\mathrm{F}=5.102 ; \mathrm{p}<0.01)$, the Tukey test showed that January was different from November, December, February and March. Regarding area $(\mathrm{F}=4.743 ; \mathrm{p}<0.01)$, the upper area was different from the middle and lower areas.

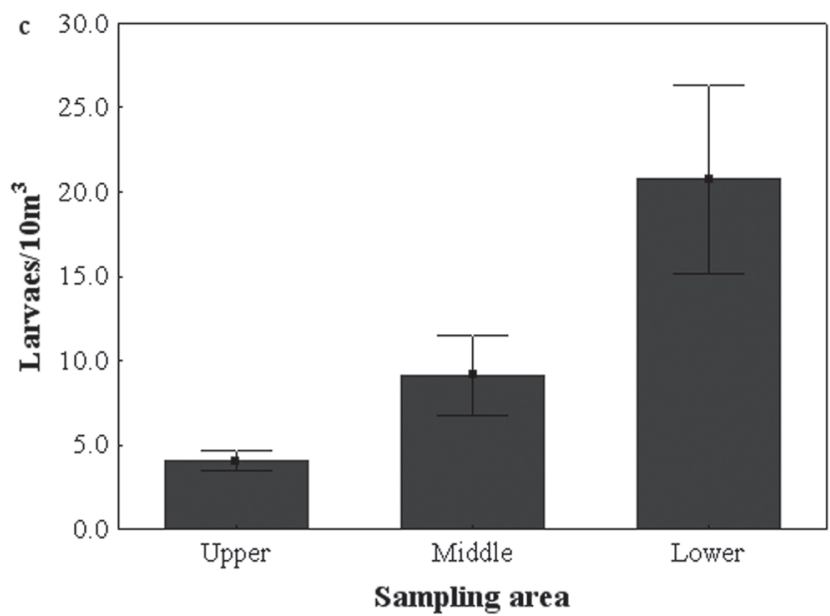

Fig. 3. Average fish larval abundances (rectangles) and standard errors (bars) by period (a), month (b) and sampling area (c) in the Ilha Grande National Park, from October 2001 to March 2005.

The highest site average of egg abundance, considering all three periods, was at site $2\left(21.07 \mathrm{eggs} / 10 \mathrm{~m}^{3}\right)$, followed by sites 3 and 13 ( 19.13 and 10.58 eggs $/ 10 \mathrm{~m}^{3}$, respectively) (Fig. 4a). The site with the highest average abundance of larvae was site $10\left(81.42\right.$ larvae/ $\left.10 \mathrm{~m}^{3}\right)$; other sites with high larval catches were sites 22 and 11 (24.35 and 19.99 larvae/ $10 \mathrm{~m}^{3}$, respectively) (Fig. $4 \mathrm{~b}$ ). 
During the study period, the water temperature varied between $20^{\circ} \mathrm{C}$ and $35^{\circ} \mathrm{C}\left(\right.$ mean \pm s.d. $\left.=28.40 \pm 2.18^{\circ} \mathrm{C}\right)$. For dissolved oxygen, the values varied between 1.90 and 12.06

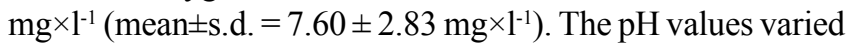
from 5.22 to 9.26 (mean \pm s.d. $=7.30 \pm 0.72$ ). The conductivity showed the highest oscillation varying from 4.00 to 90.80 $\mu \mathrm{S} \times \mathrm{cm}^{-1}$ (mean \pm s.d. $\left.=53.7 \pm 12.48 \mu \mathrm{S} \times \mathrm{cm}^{-1}\right)$. Fluviometric levels fluctuated between 132.00 and $260.00 \mathrm{~cm}$ (mean \pm s.d. $=191.80$ $\pm 38.41 \mathrm{~cm}$ ). For the rainfall, the lowest value was $1.60 \mathrm{~mm}$ and the highest was $329.00 \mathrm{~mm}$ (mean \pm s.d. $=143.00 \pm 94.72 \mathrm{~mm})$. Variability observed for each environmental variables analyzed in each period (I, II and III) and sites (upper, middle and lower) is showed in the Table 1.

Correlation analyses (Spearman ñ) between abiotic variables and the fish egg and larvae abundances were significant. Abundance of eggs had significant negative correlations with water temperature, $\mathrm{pH}$ and fluviometric level, while rainfall was significantly positively correlated (Table 2 ). The abundance of larvae was significantly negatively correlated with $\mathrm{pH}$ and positively correlated with conductivity, dissolved oxygen and rainfall (Table 2).

\section{Discussion}

The fact that fish eggs and larvae were caught during every sampling month is consistent with the findings of Vazzoler (1996), who reported that the spawning period for most species in the upper Paraná River occurs from September to March. However, the peak in the amount of eggs in October and November and the highest larval catch in January show that species reproduce primarily during these two months, and that these peaks may occur earlier or later depending on variations in environmental conditions. Interannual differences in the densities of eggs and larvae have been related to fluctuations of abiotic factors such as temperature and flow (Baumgartner et al. 1997; Reinalte-Tataje, 2007) and biotic factors such as food availability and predation (Cushing, 1990).

The differences in the abundances of fish eggs and larvae observed among the three study periods, show that abundances are decreasing over time in Ilha Grande National Park. This decreased in the abundances may be due to several factors, such as intensive farming, the presence of organic waste in the water, the construction of dams or climatic changes. Moreover, the lack of rain during the second period was probably responsible for the low catch of fish eggs and larvae in that period. Several authors suggest that rainfall is the main environmental factor modulating the reproduction of tropical fish (Godoy, 1967; Vazzoler; Menezes, 1992). Flooding during the spawning season can be very valuable for some species, due to increased food availability and refuges.

Although the effect of climatic events should not be discarded, there is evidence that one of the probable causes for the reduction in the reproductive activity of fish is directly related to the influence of dams on the Paraná River, in particular the Porto Primavera Dam (officially named Engineer Sérgio Motta). This dam is a physical barrier that interrupts migration routes of the main reophilic fish species, impeding their access to the upper reaches where they used to spawn. Sanches et al. (2006) showed that after Porto Primavera entered into operation, there was a registered decrease in

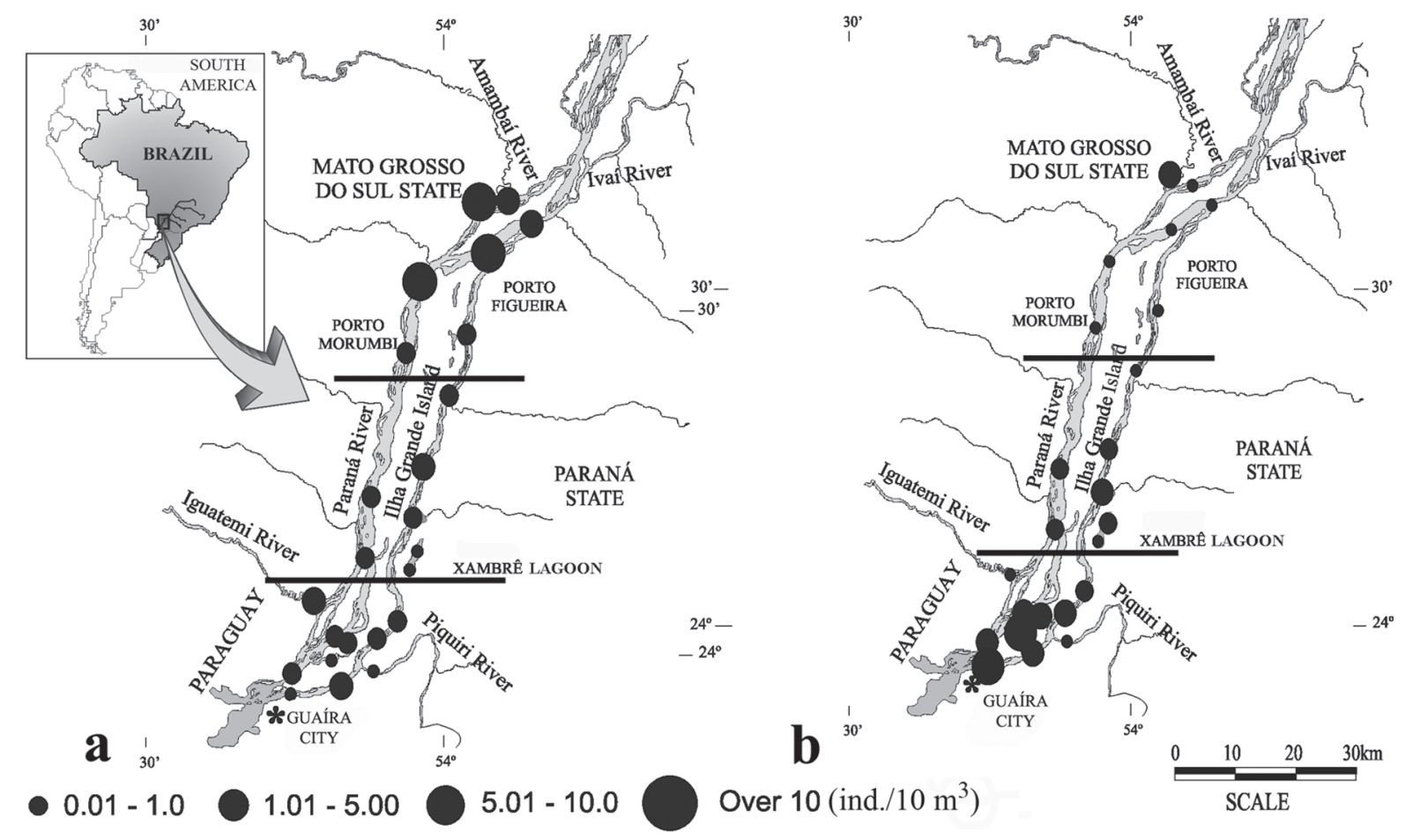

Fig. 4. Average abundance of fish eggs (a) and larvae (b) in the Ilha Grande National Park, from October 2001 to March 2005. 
Table 1. Monthly average values and standard deviations (minimum and maximum) of abiotic variables during the study in the Ilha Grande National Park. Period I - October 2001 to March 2002; Period II - October 2003 to March 2004; and Period III October 2004 to March 2005.

\begin{tabular}{|c|c|c|c|c|c|c|c|c|c|}
\hline \multirow{2}{*}{$\begin{array}{c}\text { Abiotic } \\
\text { variables }\end{array}$} & \multicolumn{3}{|c|}{ Period I } & \multicolumn{3}{|c|}{ Period II } & \multicolumn{3}{|c|}{ Period III } \\
\hline & upper & middle & lower & upper & middle & lower & upper & middle & 10 \\
\hline & 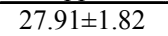 & & & & & & & & \\
\hline & & & & & & & & & \\
\hline $\mathrm{pH}$ & & $\begin{array}{r}7.41= \\
(6.11\end{array}$ & $\begin{array}{r}7.40 \\
(6.44\end{array}$ & & $\begin{array}{l}6 \\
\text { 2) }\end{array}$ & & & & \\
\hline Condutivity & & $\begin{array}{r}53.74 \\
(22.3\end{array}$ & $\begin{array}{r}54.01 \\
(17.8\end{array}$ & & $\begin{array}{r}52.51 \\
(46 .\end{array}$ & & & $\begin{array}{l}0.71 \\
9.0)\end{array}$ & \\
\hline Dissolved & $7.50 \pm 1.48$ & $\begin{array}{r}7.58= \\
5.84\end{array}$ & $\begin{array}{r}7.57= \\
5882\end{array}$ & 7.42 & $\begin{array}{r}7.45 \\
7.89\end{array}$ & 7.42 & 7.9 & 7.78 & 7.62 \\
\hline & $176.96 \pm 40.80$ & $180.20 \pm 41.57$ & $179.76 \pm 41.83$ & $173.71 \pm 20.63$ & $173.31 \pm 20.15$ & $173.13 \pm 20.39$ & $\begin{array}{l}225.49 \pm 28.80 \\
(167.0-260.0)\end{array}$ & $\begin{array}{l}222.11 \pm 31.70 \\
(167.0-260.0)\end{array}$ & $\begin{array}{l}223.07 \pm 31.42 \\
(167.0-260.0)\end{array}$ \\
\hline Rainfall (mm) & $\begin{array}{c}104.10 \pm 43.88 \\
(30.8-156.4)\end{array}$ & $\begin{array}{c}100.26 \pm 46.51 \\
(30.8-156.4)\end{array}$ & $\begin{array}{c}101.67 \pm 46.29 \\
(30.8-156.4)\end{array}$ & $\begin{array}{c}154.85 \pm 85.45 \\
(28.9-291.6)\end{array}$ & $\begin{array}{c}152.81 \pm 84.43 \\
(28.9-291.6)\end{array}$ & $\begin{array}{c}153.61 \pm 85.52 \\
(28.9-291.6)\end{array}$ & $\begin{array}{c}188.89 \pm 116.61 \\
(1.6-329.0)\end{array}$ & $\begin{array}{c}172.85 \pm 120.65 \\
(1.6-329.0)\end{array}$ & $\begin{array}{c}173.07 \pm 119.13 \\
(1.6-329.0)\end{array}$ \\
\hline
\end{tabular}

the reproductive activity of sedentary and migratory species in the region of the floodplain of the upper Paraná River, located a few kilometers above the region of the Ilha Grande National park.

When dams interrupt migratory routes of several fish species, tributaries may act as alternative routes, playing an important role in the maintenance of regional biological diversity and fish stocks (Agostinho et al., 1992; Baumgartner et al., 2004; Sanches et al., 2006). The high occurrences and abundances of eggs in the upper area of the Ilha Grande National Park indicate that the spawning can be occurring in the tributaries, mainly in the Amambaí River. This river is a tributary on the right margin of the Paraná River, and it has not been impacted much because it is free of dams and its fluviometric level is controlled entirely by the hydrological cycle. Thus, the eggs and larvae are passively transported by currents to areas of development located in the lower area of the Park, that are favorable to development of larvae, as backwaters and secondary channels with low flow velocity and marginal vegetation. In addition, this river has several marginal lagoons and extensive floodplains that make it a favorable environment for fish to spawn. Accordingly Nakatani et al. (2001), the marginal lagoons are considered natural nurseries, the eggs and larvae are passively transported by the current, and the larvae find, in this environments, abundant food and shelter.

Thereby, Ivinhema River, that drains a few kilometers above the National Park, has similar characteristics to the Amambaí River, and it is important as spawning grounds. In

Table 2. Spearman ñ correlations between abiotic variables and the abundance of fish eggs and larvae in the Ilha Grande National Park (in bold are the significative correlations; $\mathrm{p}<0.05$ ).

\begin{tabular}{lcc}
\hline \multirow{2}{*}{$\begin{array}{c}\text { Environmental } \\
\text { variables }\end{array}$} & \multicolumn{2}{c}{ Spearman Correlations } \\
\cline { 2 - 3 } & Egg & Larvae \\
\hline Water temperature $\left({ }^{\circ} \mathrm{C}\right)$ & $\mathbf{- 0 . 2 6}$ & -0.06 \\
pH & $\mathbf{- 0 . 1 3}$ & $\mathbf{- 0 . 2 0}$ \\
Conductivity $(\mu \mathrm{S} / \mathrm{cm})$ & 0.09 & $\mathbf{0 . 1 1}$ \\
Dissolved oxygen $\left(\mathrm{mg} .1^{-1}\right)$ & -0.05 & $\mathbf{0 . 1 6}$ \\
Fluviometric level $(\mathrm{cm})$ & $\mathbf{- 0 . 1 4}$ & 0.04 \\
Rainfall $(\mathrm{mm})$ & $\mathbf{0 . 1 2}$ & $\mathbf{0 . 1 8}$ \\
\hline
\end{tabular}

this river, the eggs are also carried passively by the current and are released into the Paraná River channel (Sanches et al., 2006). The addition of the spawning in this tributarie may be explains the high catches at site 1 . Whereas, the catches recorded at site 21, located in the lower region of the National Park, may be explained by the spawning in the Piquiri River, a tributary of the left margin of the Paraná River.

Tributaries from both margins of the Paraná River currently constitute the only migratory routes for fishes because the main channel of the Paraná River is blocked by the Porto Primavera Dam. According to Sanches et al. (2006), before the Porto Primavera Dam was built, larvae of migratory fishes like "dourado" (Salminus brasiliensis) and "pintado" (Pseudoplatystoma corruscans) were caught at many places in the Paraná River. After dam construction, these larvae have only been caught in the tributaries, mainly, Ivinhema River. However, recent studies have been showing that impacts caused by dams located downstream and upstream of spawning and nursery areas and tributaries are stronger than previously reported (Gubiani et al., in press).

According to Nakatani et al. (1997) and Baumgartner et al. (2004), migratory species seek the headwaters of rivers to spawn, and their eggs are carried by currents to feeding and growth areas that favor larval survival. These authors point out that during this trip the embryos even complete their development until eclosion, which can explain the higher capture of larvae at the sites located in the lower area of the Ilha Grande National Park. This trend of a higher abundance of eggs upstream and greater larval abundance downstream was demonstrated previously by Nakatani et al. (1997) in the Ivinheima, Iguatemi and Piquiri Rivers and by Baumgartner et al. (2004) in the Amambaí and Ivaí Rivers, which all belong to the upper Paraná River basin.

Although apparently the tributaries are spawning sites, not rule out the hypothesis of the main channel of the Paraná River is used for spawning and growth of sedentary species that not have their life-cycle-dependent increase in river level. ReinalteTataje et al. (2008) reported the development of larvae non migratory in a small stretch of the River Uruguay. The high occurrence of larvae at the sites that are located in the Saraiva 
lagoon indicates that this environment may be considered as a nursery and foraging site for larvae. Its characteristics (for $e . g$., dense plant cover, reduced flow and permanent connection to the river) provide the ideal conditions to promote survival during the initial development phases.

Lagoons in the floodplains of large rivers are known for their importance as natural nurseries for juvenile fish (Welcomme, 1985; Bayley \& Li, 1996). Tondato et al. (2010) affirm that marginal lagoons are important reproduction sites for many sedentary species of the floodplain of the Cuiabá River. In the upper Paraná River floodplain, Nakatani et al. (1997) showed that the lagoons are true nurseries offering shelter and food. In the Ilha Grande National Park, Daga et al. (2009) showed the importance of two marginal lagoons for initial development of fishes. These authors found high abundances of fish larvae, both resident and migratory species, mainly in Saraiva lagoon. The importance of this lagoon for the development of fish species is also highlighted by Brunetto (unpublished data), who found larvae of "dourado" (Salminus brasiliensis) in advanced stages of development near to Saraiva Lagoon, that is located in the lower area of the Ilha Grande National Park.

As fish reproduction is a physiologically cyclical process, in which the patterns of frequency have a direct relationship with environmental conditions (Lowe-McConnel, 1987; Munro, 1990), environmental variables, especially temperature, rainfall, dissolved oxygen, electrical conductivity and fluviometric level, act to regulate reproduction (Vazzoler, 1996; Baumgartner et al., 2004). Various researchers have discussed the influence of rainfall and the subsequent increase in fluviometric level on fish reproduction. LoweMcConnel (1987), Munro (1990) and Vazzoler (1996) reported that these exogenous factors might influence spawning by signaling favorable conditions that maximize larval survival. In the present study, the Pearson and Spearman correlations indicated that egg abundance was significantly influenced by temperature, $\mathrm{pH}$, fluviometric level and rainfall, and that larval density was influenced by $\mathrm{pH}$, conductivity, dissolved oxygen and rainfall. Although some have been observed extreme values of some variables (especially dissolved oxygen and electrical conductivity), very low correlation may be indicating that eggs and larvae were more related to intermediate values of environmental variables.

Several ecologists have studied the close relationships between the abundances of fish eggs and larvae and abiotic variables in the floodplain of the upper Paraná River. Baumgartner et al. (1997), Bialetzki et al. (2004) and Baumgartner et al. (2008) found similar results to that obtained in this study. Baumgartner et al. (2008) showed in their conceptual model that the larvae of different species have different relationships with abiotic variables. However, these studies were performed with data obtained before to the closure of Porto Primavera Dam and only studies with longer be possible to achieve a more accurate diagnosis of the effects of environmental variables on the ichthyoplankton on current conditions in the Paraná River.
Water temperature is one of the most important factors in fish life cycle, may increase or decrease the rate of metabolic processes. An increase in body temperature increases the kinetic energy of atoms and molecules, facilitating chemical reactions and inter and intramolecular bonds, which modifies the equilibrium of reactions between proteins (enzymesubstrate, hormone-receptor for example) (Baldisserotto, 2002). The highest reproductive intensity of most species in the upper Paraná River (Vazzoler, 1996) and upper Uruguay River (Hermes-Silva et al., 2009) occurs between October and January, when water temperature are highest.

As well as temperature, rainfall and river level also influenced the abundance of catches of eggs and larvae. Most migratory fish have a reproductive cycle that is intimately connected to the rainfall and flood regime, spawning in open water and eggs and larvae are pelagic and drift to flooded areas and marginal lagoons (Agostinho et $a l ., 2004)$. If there is no flood, the eggs and larvae stay in the main channel of the river and are susceptible to predation by fish and other aquatic organisms (Sanches et al., 2006). Water level is the main factor acting on tropical fish communities (Lowe-McConnell, 1987; Vazzoler, 1996) and can to affect species composition (Agostinho et al., 1997). Baumgartner et al. (2008), present a conceptual model showing that several migratory species have the greatest abundance of capture in periods of high level and rainfall. Sanches et al. (2006) also showed that even non-migratory species were affected after the control flow generated by the closure of Porto Primavera Dam.

The oscillation of the river level as it influences the reproduction of fish, also influences a number of limnological variables. The levels of dissolved oxygen, $\mathrm{pH}$ and electrical conductivity, in this study, may have been influenced by the samples in the Saraiva Lagoon in times of high water, where the oxygen content in water and the $\mathrm{pH}$ is low and the high electrical conductivity in response to increase of the decomposition of submerged organic matter (Pagioro, 1996). Thomaz et al. (1997) found similar results for lagoons in the floodplain of the upper Paraná River. Nascimento \& Nakatani (2006) obtained similar results; they observed that the low values to $\mathrm{pH}$ and electrical conductivity were related to high precipitation, have positively influenced the abundance of eggs and larvae. Although it is not clear how to $\mathrm{pH}$ and electrical conductivity affect the reproductive process, in some manner they induce spawning for some species, as descript in Baumgartner et al. (2008). Vazzoler (1996) considers these variables as factors synchronizers for spawning.

Data from three periods of spawning analyzed in this study show that the upper region of the Ilha Grande National Park, specifically the tributaries Amambaí and Ivinheima (outside the area of the park), can be considered as the spawning area, the middle stretch drift area and the lower stretch larval development area, especially Saraiva Lagoon and secondary channels (Daga et al., 2009). Finding the largest catches of eggs in the tributaries, that are free from flow control and their downstream areas of influence, shows that the spawning 
areas are under the direct influence of the elevation of the fluviometric level. Although the larvae caught have not been identified, apparently, the species are looking for these tributaries, mainly located in the right margin, as migratory routes. A similar phenomenon was observed by Hermes-Silva et al. (2009), the upper Uruguay River, where the authors report that the largest catches of eggs in the tributaries and regards them as alternative migration routes. According to these authors, the presence of dams contributes to the reduction in catches of eggs and larvae in the Uruguay River. The lowest abundance of catches in sites located in the main channel of the Paraná River may also have been influenced by dams, mainly related to control the river level and the modification of the flood, as discussed by Sanches et al. (2006) and Agostinho et al. (2007).

The oscillation in water level (flood and drought) is a key factor driving the ecological functioning and biodiversity patterns in river-floodplain systems (Junk et al., 1989; Neiff 1990; Thomaz et al., 2007). Dams can change the hydrologic regime of the river downstream by damping fluctuations in water levels. Reducing flood peaks decreases the area flooded and, consequently, the connectivity between the river and isolated floodplain habitats (Petry et al., 2003; Agostinho et al., 2007; Gubiani et al., 2007). For fish assemblages in Ilha Grande National Park, Baumgartner et al. (in press) observed that reduced connectivity and flooding may be responsible for observed differences in fish assemblage composition and structure among the different biotopes, as marginal lagoons, tributaries and main channel of the Paraná River. Thus, impacts in the patterns of distribution of eggs and larvae of fish in Ilha Grande National Park are expected if alterations in water level happen.

The presence of dams has created an irreversible impact, mainly modifying natural pulses of the flood and drought that could be damaging the spawning of species that have reproductive cycles that are dependent upon the elevation of the fluviometric level. The impact would be even more severe without the accessibility of these tributaries to migratory fish, and these tributaries, together with the lagoon Saraiva, are extremely important for fish reproduction. Measures for preserving these environments should be developed and encouraged.

\section{Acknowledgements}

The authors thank the Universidade Paranaense for financial support, and the team of the Consorcio Intermunicipal para a Conservação do Remanescente das Várzeas do Rio Paraná and the Instituto Ambiental do Paraná (IAP) for field work support.

\section{Literature Cited}

Agostinho, A. A., L. C. Gomes \& F. M. Pelicice. 2007. Ecologia e Manejo de Recursos Pesqueiros em Reservatórios do Brasil. Maringá, Eduem, 507p.
Agostinho, A. A., H. F. Júlio Jr. \& J. R. Borghetti. 1992. Considerações sobre os impactos dos represamentos na ictiofauna e medidas para sua atenuação. Um estudo de caso: Reservatório de Itaipu. Revista Unimar, 14(supl.): 89-107.

Agostinho, A. A., H. F. Júlio Jr., L. C. Gomes, L. M. Bini \& C. S. Agostinho. 1997. Composição, abundância e distribuição espaço-temporal da ictiofauna. Pp. 179-208. In: Vazzoler, A. E. A. M., A. A. Agostinho \& N. S. Hahn (Eds.). A planície de inundação do alto rio Paraná: aspectos físicos, biológicos e socioeconômicos. Maringá, Eduem, 460p.

Agostinho, A. A., S. M. Thomaz \& L. C. Gomes. 2004. Threats for biodiversity in the floodplain of the upper Paraná River: effects of hydrological regulation by dams. Ecohydrology \& hydrobiology, 4(3): 267-280.

Agostinho, A. A., A. E. A. M. Vazzoler \& S. M. Thomaz. 1995. The high Paraná River basin: limnological and ichthyological aspects. Pp. 59-103. In: Tundisi J. G., C. E. M. Bicudo \& T. Matsumura-Tudinsi (Eds.). Limnology in Brazil. Rio de Janeiro, ABC/SBL.

Baldisserotto, B. 2002. Fisiologia de peixes aplicada à piscicultura. Santa Maria, Editora da UFSM, 212p.

Baumgartner, G., É. A. Gubiani, R. L. Delariva \& P. V. Sanches. In press. Spatial patterns in fish assemblages of Ilha Grande National Park, Brazil. Wetlands.

Baumgartner, G., K. Nakatani, M. Cavicchioli \& M. S. T. Baumgartner. 1997. Some aspects of the ecology of fish larvae in the floodplain of the high Paraná river, Brazil. Revista Brasileira de Zoologia, 14(3): 551-56.

Baumgartner, G., K. Nakatani, L. C. Gomes, A. Bialetzki, P. V. Sanches \& M. C. Makrakis. 2004. Identification of spawning sites and natural nuseries of fishes in the upper Paraná River, Brazilian Environmental Biology of Fishes, 71(2): 115-125.

Baumgartner, G., K. Nakatani, L. C. Gomes, A. Bialetzki, P. V. Sanches \& M. C. Makrakis. 2008. Fish larvae from the upper Paraná River: Do abiotic factors affect larval density? Neotropical Ichthyology, 6(4): 551-558.

Bayley, P. B. \& H. W. Li. 1996. Riverine fishes. Pp. 92-122. In: Calow, P. \& G. Petts (Eds.). River biota: diversity and dynamics. London, Blackwell Science, 257p.

Bialetzki, A., K. Nakatani, P. V. Sanches \& G. Baumgartner. 2004. Eggs and larvae of the 'curvina' Plagioscion squamosissimus (Heckel, 1840) (Osteichthyes, Sciaenidae) in the Baía River, Mato Grosso do Sul State, Brazil. Journal of Plankton Research, 26(11): 1327-1336.

Campos, J. B. 2001. Parque Nacional de Ilha Grande re-conquista e desafios. Maringá, IAP/CORIPA.

Conover, W. J. \& R. L. Iman. 1981. Rank transform as a bridge between parametric and nonparametric statistics. The American Statistician, 35: 124-133.

Daga, V. S., T. M. Gogola, P. V. Sanches, G. Baumgartner, D. Baumgartner, P. A. Piana, É. A. Gubiani \& R. L. Delariva. 2009. Fish larvae assemblages in two floodplain lakes with different degrees of connection to the Paraná River, Brazil. Neotropical Ichthyology, 7(3): 429-438.

Gubiani, É. A., L. C. Gomes, A. A. Agostinho \& E. K. Okada. 2007. Persistence of fish populations in the upper Paraná River: effects of water regulation by dams. Ecology of Freshwater Fish, 16(2): 191-197.

Gubiani, É. A., L. C. Gomes, A. A. Agostinho \& G. Baumgartner. In press. Variations in fish assemblages in a tributary of the upper Paraná River, Brazil: a comparison between pre and post-closure phases of dams. River Research and Applications. 
Hermes-Silva, S., D. R. Tataje \& E. Z. Filho. 2009. Spatial and Temporal Distribution of Ichthyoplankton in the upper Uruguay River, Brazil. Brazilian Archives of Biology and Technology, 52(4): 933-944.

Junk, W. J., P. B. Bayley \& R. E. Sparks. 1989. The flood pulse concept in river-floodplain systems. In: Dodge, D. P. (Ed.). Proceedings of the International Larger River Symposium. Canadian Special Publication of Fisheries and Aquatic Sciences, 106: 110-127.

Lowe-McConnel, R. H. 1987. Ecological studies in tropical fish communities. Cambridge, Cambridge University Press, 382p.

Matsuura, Y. A. 1977. A study of the life History of brazilian sardine, Sardinella brasiliensis. IV. Distribution and abundance of sardine larvae. Boletim do Instituto Oceanográfico de São Paulo, 26: 219-247.

Miller, T. J. 2002. Physical and ecological process in ichthyoplankton assemblages. In: Fuiman, L. A. \& R. G. Werner (Eds.). Concepts in fishery science: the unique contributions of early life stages. New York, Blackwell Sciences.

Munro, A. D. 1990. General introduction. In: Scott, A. P. \& T. J. Lam (Eds.). Reproductive Seasonality in Teleosts: Environmental Influencies. Boca Raton, CRS Press, 254p.

Nakatani, K., A. A. Agostinho, G. Baumgartner, A. Bialetzki, P. V. Sanches, M. C. Markrakis \& C. Pavanelli. 2001. Ovos e larvas de peixe de água doce: Desenvolvimento e manual de identificação. Maringá, Eduem/Nupelia.

Nakatani, K., G. Baumgartner \& M. S. T. Baumgartner. 1997. Larval development of Plagioscion squamosissimus (HECKEL) (Perciformes, Scianidae) of Itaipu reservoir (Paraná River, Brazil). Revista Brasileira de Zoologia, 14(1): 35-44.

Nascimento, F. L. \& K. Nakatani. 2006. Relações entre fatores ambientais e a distribuição de ovos e larvas de peixes na subbacia do rio Ivinhema, Estado do Mato Grosso do Sul, Brasil. Acta Scientiarum, Biological Sciences, 28(2): 117-122.

Neiff, J. J. 1990. Ideas para la interpretacion ecologica del Paraná. Interciência, 15: 424-441.

Nilsson, C. \& K. Berggren. 2000. Alterations of riparian ecosystems caused by river regulation. Bioscience, 50: 783-792.

Pagioro, T. A. 1996. Decomposição de duas populações distintas de Eichhornia azurea (Swartz) Kunth da planície de inundação do alto rio Paraná. Unpublished MSc Dissertation, Universidade Estadual de Maringá, Maringá, 37p.

Petry, A. C., A. A. Agostinho \& L. C. Gomes. 2003. Fish assemblages of tropical floodplain lagoons: exploring the role of connectivity in a dry year. Neotropical Ichthyology, 1: 111-119.

Quinn, G. P. \& M. J. Keough. 2002. Experimental design and data analysis for biologists. Cambridge, Cambridge University Press, 537p.

Reynalte-Tataje, D. A. 2007. Influência das variáveis ambientais na distribuição espaço-temporal do ictioplâncton em duas bacias hidrográficas brasileiras. Unpublished Ph.D. Thesis, Programa de Pós-Graduação em Ecologia de Ambientes Aquáticos Continentais, Universidade Estadual de Maringá, Maringá, 119p.

Reynalte-Tataje, D. A., S. H. Silva, M. M. de C. Silva, F. M. Abbud, R. N. Correa \& E. Z. Filho. 2008. Distribuição de ovos e larvas de peixes na área de influência do reservatório de Itá (Alto Rio Uruguai). Pp. 127-158. In: Filho, E. Z \& A. P. de O. Nuñer (Eds.). Reservatório de Itá: Estudos ambientais, desenvolvimento de tecnologias de cultivo e conservação da ictiofauna. Florianópolis, Editora da UFSC, 319p.

Sanches, P. V., K. Nakatani, A. Bialetzki, G. Baumgartner \& E. A. Luiz. 2006. Flow regulation dams affecting ichthyoplankton: the case of Porto Primavera Dam, Paraná River, Brazil. River Research and Applications, 22: 555-565.
Tanaka, S. 1973. Stock Assessment By Means Of Ichthyoplankton Surveys. FAO Fisheries Technical Paper, 122: 33-51.

Thomaz, S. M., L. M. Bini \& R. L. Bozelli. 2007. Floods increase similarity among aquatic habitats in river-floodplain systems. Hydrobiology, 579: 1-13.

Thomaz, S. M., M. C. Roberto \& L. M. Bini. 1997. Caracterização liminológica dos ambientes aquáticos e influência dos níveis fluviométricos. Pp. 73-102. In: Vazzoler, A. E. A. M., A. A. Agostinho \& N. S. Hahn (Eds.). A planície de inundação do alto rio Paraná: aspectos físicos, biológicos e socioeconômicos. Maringá, Eduem, 460p.

Tondato, K. K., L. A. de F. Mateus \& S. R. Ziober. 2010. Spatial and temporal distribution of fish larvae in marginal lagoons of Pantanal, Mato Grosso State, Brazil. Neotropical Ichthyology, 8(1): 123-133.

Tundisi, J. G. 1999. Reservatórios como sistemas complexos: teoria, aplicações e perspectivas para usos múltiplos. Pp. 19-38. In: Henry, R. (Ed.). Ecologia de reservatórios: estrutura, função e aspectos sociais. Botucatu, Fundibio; São Paulo, Fapesp.

Vazzoler, A. E. A. de M. 1996. Biologia da reprodução de peixes teleósteos teoria e prática. Maringá, Eduem, 163 p.

Vazzoler, A. E. A. M. \& N. A. Menezes. 1992. Síntese do conhecimento sobre o comportamento reprodutivo dos Characiformes da América do Sul (Teleostel, Ostariophysi). Revista Brasileira de Biologia, 52(4): 627-640.

Welcomme, R. L. 1985. River Fisheries. FAO Fisheries Technical Papper 262. Rome: Food and Agriculture Organization of the United Nations.

Zar, J. H. 1999. Biostatistical Analysis. Upper Saddle River, NJ, Prentice Hall.
Accepted May 17, 2010

Published June 25, 2010 